\title{
Pathways of carbon oxidation in an Arctic fjord sediment (Svalbard) and isolation of psychrophilic and psychrotolerant Fe(III)-reducing bacteria
}

\author{
Verona Vandieken $^{1,2, *}$, Niko Finke ${ }^{1,2}$, Bo Barker Jørgensen ${ }^{1}$ \\ ${ }^{1}$ Max Planck Institute for Marine Microbiology, Celsiusstrasse 1, 28359 Bremen, Germany \\ ${ }^{2}$ Present address: Exobiology Branch, NASA Ames Research Center, Mail Stop 239-4, Moffet Field, California 94035-1000, USA
}

\begin{abstract}
The main mineralization pathways were determined in permanently cold fjord sediment on the west coast of Svalbard. In whole core incubations, the total oxygen uptake rate was $4.2 \pm 0.4 \mathrm{mmol} \mathrm{m}^{-2} \mathrm{~d}^{-1}$ and the sulfate reduction rate $2.6 \pm 0.6 \mathrm{mmol} \mathrm{m} \mathrm{m}^{-2} \mathrm{~d}^{-1}$ at 0 to $20 \mathrm{~cm} \mathrm{depth}$. Sulfate reduction was the most important anaerobic mineralization process, accounting for $57 \%$ of anaerobic organic carbon oxidation in anoxic bag incubations of the top $5 \mathrm{~cm}$ of the sediment. The remaining $43 \%$ oxidation was attributed to microbial Fe(III) reduction. Both processes occurred concurrently in the uppermost $2 \mathrm{~cm}$, and the Fe-reducing community appeared to be limited mainly by the availability of Fe(III). Below $2 \mathrm{~cm}$, sulfate reduction was the dominant electron-accepting process. Calculations for the uppermost $10 \mathrm{~cm}$ of the sediment yielded the following contribution of the different respiratory pathways to total carbon oxidation: aerobic respiration $53 \%$, sulfate reduction $34 \%$, Fe(III) reduction $13 \%$. In situ, the importance of Fe(III) reduction may vary through competition for substrate with oxygen- and nitrate-reducing bacteria in the surface sediment. Fe(III)-reducing bacteria belonging to the genera Desulfuromonas, Desulfuromusa, Shewanella and Desulfovibrio were isolated from enrichment cultures of 2 fjord sediments from Svalbard. Strains related to Desulfovibrio reduced Fe(III) without energy generation for growth. All isolates were psychrophilic or psychrotolerant and grew at $-2^{\circ} \mathrm{C}$, the freezing point of sea water, indicating adaptation to permanently cold temperatures. Besides Fe(III), the strains reduced other electron acceptors such as oxygen, manganese, elemental sulfur and sulfate.
\end{abstract}

KEY WORDS: Fe reduction · Sulfate reduction · Psychrophiles · Fe(III)-reducing bacteria · Isolation • Svalbard $\cdot$ Sediment bag incubation

Resale or republication not permitted without written consent of the publisher

\section{INTRODUCTION}

The exploration of permanently low temperature environments is motivated by their quantitative importance, as $90 \%$ of the ocean floor permanently has temperatures below $5^{\circ} \mathrm{C}$ (Levitus \& Boyer 1994). Benthic microbial processes are controlled, among other things, by temperature and by substrate availability. The annual primary production in southern fjords of Svalbard is estimated to be $\sim 150 \mathrm{~g} \mathrm{C} \mathrm{m}^{-2} \mathrm{yr}^{-1}$ and comparable to that of more southern latitudes where there is no significant ice coverage (Eilertsen et al. 1989). Thus, the organic carbon deposition to the sediment is correspondingly high. The organic carbon content in sediments along the west and south coasts of Svalbard is higher than on the north and east coasts, where the periods of ice coverage are longer, resulting in lower primary productivity (Hulth et al. 1996). The degradation of organic matter arriving at the sea floor involves a complex bacterial food web. Metabolic end-products of some bacteria can serve as substrates for others (e.g. fermentation products are substrates for $\mathrm{Mn}-$, Fe- and sulfate-reducing bacteria). A sequence of respiratory processes with different inorganic electron acceptors $-\mathrm{O}_{2}, \mathrm{NO}_{3}{ }^{-}, \mathrm{Mn}(\mathrm{IV}), \mathrm{Fe}(\mathrm{III})$ and $\mathrm{SO}_{4}{ }^{2-}$ - is responsible for the complete degradation to $\mathrm{CO}_{2}$. Studies on 
metabolic rates of different microbial processes in the sediment have shown that the rates of organic carbon turnover in Arctic coastal sediments are as high as in comparable temperate sediments (Arnosti et al. 1998, 2005, Sagemann et al. 1998, Thamdrup \& Fleischer 1998, Kostka et al. 1999). Thus, the benthic microbial communities in Arctic sediments do not seem to be limited by low temperature but rather by organic carbon availability (Glud et al. 1998, Rysgaard et al. 1998).

In 3 permanently cold fjord sediments of Svalbard, sulfate reduction was found to be the dominant terminal electron accepting process (58 to $92 \%$ of total mineralization; Kostka et al. 1999). In 2 of the 3 sediments studied, microbial Fe reduction was the second most important anaerobic respiration pathway (10 and $26 \%$ ), while it was below detection at the third station. In Arctic fjord sediments on the east coast of Greenland, Fe reduction accounted for 21 to $26 \%$ of total carbon oxidation (Rysgaard et al. 1998, Glud et al. 2000). These studies, together with studies in temperate coastal sediments, determined an average contribution of $17 \%$ of $\mathrm{Fe}$ reduction to total carbon mineralization for coastal marine sediments (reviewed by Thamdrup 2000).

Bacteria able to respire with Fe(III) are phylogenetically diverse (Lovley et al. 2004). Most species of the Geobacteraceae within the $\delta$-Proteobacteria (including the genera Desulfuromonas, Geobacter, Pelobacter, Malonomonas and Desulfuromusa) are able to reduce both Fe(III) and elemental sulfur (Holmes et al. 2004b, Lovley et al. 2004). In a Svalbard fjord sediment $13 \%$ of clones in a bacterial 16S rDNA clone library were most closely related to Desulfuromonas species (Ravenschlag et al. 1999), indicating that this group might contribute to the iron- and sulfur-cycles in permanently cold sediment. Psychrophilic, Fe-reducing bacteria of the genus Shewanella within the $\gamma$-Proteobacteria have been isolated from Antarctic and Arctic sea ice as well as from Antarctic sediments (Bowman et al. 1997b, 2003, Bozal et al. 2002, Brinkmeyer et al. 2003). A contribution of sulfate-reducing bacteria of the genus Desulfovibrio to benthic Fe reduction was suggested from pure-culture studies and biomarker analyses of saltmarsh sediments (Coleman et al. 1993, Lovley et al. 1993, Li et al. 2004).

Fe-reducing species belonging to the Geobacteraceae, Shewanella, and Desulfovibrio can alternatively use other environmentally important electron acceptors such as oxygen, nitrate, Mn(IV) oxide, elemental sulfur and sulfate, or they may grow by fermentation. Therefore, the isolation of these bacteria from natural sediment samples does not imply Fe-reducing activity in situ. However, the isolation and characterization of bacteria in pure culture provides a good approach for identifying their potential activities and studying their adaptation to the ambient environmental conditions, e.g. temperature, $\mathrm{pH}$ or salinity. Bacteria isolated from permanently cold habitats such as sea ice or sediments have revealed adaptation to low temperatures (Bowman et al. 1997a, 2003, Knoblauch \& Jørgensen 1999). Sulfate-reducing and sulfuroxidizing bacteria with temperature optima ranging from 7 to $18^{\circ} \mathrm{C}$ and with the ability to grow at $-2^{\circ} \mathrm{C}$, the freezing point of sea water, have been isolated from fjord sediments of Svalbard (Knoblauch et al. 1999, Knittel et al. 2005).

The aim of the present study was to identify bacteria potentially contributing to the Fe- and sulfur cycles in fjord sediments on the west coast of Svalbard and to investigate the importance of Fe(III) reduction for the degradation of organic carbon in one of the fjord sediments.

\section{MATERIALS AND METHODS}

Site and sampling. Marine sediments were sampled during 3 cruises in fjords along the west coast of Svalbard. Details of the stations are given in Table 1. Enrichment and isolation were started with marine sediment from a cruise in September 2001 to Stns CC, $\mathrm{CD}$ and J. Anoxic bag incubation experiments with Stn $\mathrm{J}$ sediment were performed on the second cruise in August 2003. The concentrations of DIC, $\mathrm{Fe}^{2+}$, sulfate and sulfide in the pore water and the content of solidphase Fe and Mn were measured in a sediment core from cruises to Stn J in 2003 and 2004, while concentrations of ammonium and elemental sulfur, total oxygen uptake rates, dissolved inorganic carbon (DIC) production rates and sulfate reduction rates were measured in sediment cores from Stn J in August 2004. In

Table 1. Sampling site and Fe content at 3 stations (CC, CD, J) along west coast of Svalbard. Temperature and Fe content for Stn J are means $( \pm$ SE) for the 3 yr. nd: not determined

\begin{tabular}{|lccc|}
\hline Description & $\begin{array}{c}\mathrm{CC} \\
\text { Tempel- } \\
\text { fjorden }\end{array}$ & $\begin{array}{c}\mathrm{CD} \\
\text { Tempel- } \\
\text { fjorden }\end{array}$ & $\begin{array}{c}\text { Smeerenburg- } \\
\text { fjorden }\end{array}$ \\
\hline Latitude & $78^{\circ} 26.04^{\prime} \mathrm{N}$ & $78^{\circ} 25.27^{\prime} \mathrm{N}$ & $79^{\circ} 42.01^{\prime} \mathrm{N}$ \\
Longitude & $17^{\circ} 19.72^{\prime} \mathrm{E}$ & $17^{\circ} 08.27^{\prime} \mathrm{E}$ & $11^{\circ} 05.20^{\prime} \mathrm{E}$ \\
Water depth $(\mathrm{m})$ & 37 & 64 & 212 \\
Bottom-water temperature $\left({ }^{\circ} \mathrm{C}\right)$ & 3.1 & 2.8 & $1.5 \pm 0.9$ \\
Sampling year $(\mathrm{s})$ & 2001 & 2001 & 2001,2003, \\
Avg. total Fe content $\left(\mu \mathrm{mol} \mathrm{cm}{ }^{-3}\right)$ & nd & 91.9 & $78.0 \pm 1.8$ \\
\hline
\end{tabular}


general, the concentrations and depth distributions were similar in 2003 and 2004. Therefore, we present only the complete data set from 2004.

Sediment cores of $14 \mathrm{~cm}$ diameter and up to $40 \mathrm{~cm}$ length were retrieved by a Haps corer (Kanneworff \& Nicolaisen 1973), and subcores were stored on the ship at in situ temperature. In laboratories in Ny Ålesund or Longyearbyen, the sediments were stored at $0^{\circ} \mathrm{C}$ and handled outdoors at air temperatures between 0 and $5^{\circ} \mathrm{C}$ to prevent warming of the sediment.

The sediment of Stn J was characterized by extensive bioturbation, apparent from abundant polychaete tubes and polychaetes in the upper $20 \mathrm{~cm}$ of the sediment. On the surface of the sediment, brittle stars were observed. The total organic carbon content of the sediment was $2 \%$.

Anoxic bag incubations. For the anoxic bag incubations in 2003, sediment from Stn J was sliced into $1 \mathrm{~cm}$ depth intervals and transferred into gastight plastic bags under a constant stream of $\mathrm{N}_{2}$. The bags were incubated at $0^{\circ} \mathrm{C}$ in the dark inside a larger $\mathrm{N}_{2}$-filled bag to ensure anoxia. Subsamples for pore water and solid phase analyses were withdrawn 10 times from each bag over a period of $7 \mathrm{~d}$.

Sampling. Pore water was squeezed by a pore water press under $\mathrm{N}_{2}$ through GF/F filters. Pore water was filtered directly into Ferrozine-solution to measure $\mathrm{Fe}^{2+}$ (see later subsection). We collected $1.8 \mathrm{ml}$ aliquots for DIC analysis in glass vials without headspace, and either measured these within $2 \mathrm{~d}$, or fixed the samples with $\mathrm{HgCl}_{2}$ and stored them at $4^{\circ} \mathrm{C}$ until analysis. We froze 1 to $2 \mathrm{ml}$ of pore water for $\mathrm{NH}_{4}{ }^{+}, \mathrm{NO}_{3}{ }^{-}$and $\mathrm{NO}_{2}{ }^{-}$ analysis. For $\mathrm{Mn}^{2+}$ and $\mathrm{Ca}^{2+}$ determination, 0.5 to $2 \mathrm{ml}$ were acidified with $6 \mathrm{M} \mathrm{HCl}$ and stored at $4^{\circ} \mathrm{C}$. Pore water for sulfate and sulfide analyses was preserved with $\mathrm{Zn}$ acetate or $\mathrm{ZnCl}_{2}$. Sediment for analysis of reactive $\mathrm{Fe}$ was extracted in $\mathrm{HCl}$ from separate samples. For extraction of Fe and Mn with dithionite, subsamples were stored frozen at $-21^{\circ} \mathrm{C}$. For analysis of elemental sulfur, a subsample of 0.5 to $2 \mathrm{~g}$ sediment was mixed in $2 \mathrm{ml} 20 \% \mathrm{Zn}$ acetate and stored frozen at $-21^{\circ} \mathrm{C}$. Bottom water from Stn J was frozen for determination of $\mathrm{NO}_{3}{ }^{-}$and $\mathrm{NO}_{2}{ }^{-}$.

Pore water analyses. DIC was analyzed by flow injection with conductivity detection (Hall \& Aller 1992). Fe(II) was measured spectrophotometrically according to Stookey (1970) with Ferrozine $\left(1 \mathrm{~g} \mathrm{l}^{-1}\right.$ in $50 \mathrm{mM}$ HEPES buffer, $\mathrm{pH} 7$ ) at $562 \mathrm{~nm}$ (Shimadzu UV 1202). $\mathrm{NO}_{3}{ }^{-}$and $\mathrm{NO}_{2}{ }^{-}$were measured using a $\mathrm{NO}_{\mathrm{x}}{ }^{-}$ analyzer (Thermo Environmental Instruments) (Braman \& Hendrix 1989). $\mathrm{NH}_{4}{ }^{+}$samples were analyzed spectrophotometrically at $630 \mathrm{~nm}$ (Shimadzu UV 1202) (Grasshoff et al. 1999). $\mathrm{Ca}^{2+}$ and $\mathrm{Mn}^{2+}$ were measured by inductively-coupled plasma atomic emission spectrometry (Perkin Elmer Optima 3300 RL). Sulfate was analyzed by non-suppressed ion chromatography (Waters, Column IC-Pak ${ }^{\mathrm{TM}}, 50 \times 4.6 \mathrm{~mm}$ ). Sulfide was determined by the methylene blue spectrophotometric method at $670 \mathrm{~nm}$ (Shimadzu, UV 1202) (Cline 1969).

Solid phase analyses. Particulate $\mathrm{Mn}$ and Fe were quantified after extraction with dithionite-citrateacetic acid (Canfield 1989). The extract was analyzed by flame atomic absorption spectrometry for Mn concentrations (Perkin Elmer, Atomic Absorption Spectrometer 3110). Quantification of Fe from the dithionitecitrate-acetic acid extraction resulted in a lower $\mathrm{Fe}$ content compared to parallel $\mathrm{HCl}$ extractions $(0.5 \mathrm{M}$ $\mathrm{HCl}$ for $1 \mathrm{~h}$ ), therefore only the results of the $\mathrm{HCl}$ extraction are presented. The $\mathrm{HCl}$-extracts were analyzed for Fe(II) with Ferrozine and for total $\mathrm{Fe}$ (Fe(III) + Fe(II)) with Ferrozine $+1 \%(\mathrm{w} / \mathrm{v})$ hydroxylamine hydrochloride. Freeze-dried samples for determination of total organic $\mathrm{C}$ content were pretreated with $\mathrm{HCl}$, dried, and analyzed using a CNS analyzer (Fisons ${ }^{\mathrm{TM}} \mathrm{Na} 1500$ elemental analyzer). Elemental sulfur was analyzed according to Zopfi et al. (2004). With a Zorbax ODS column $(125 \times 4 \mathrm{~mm}, 5 \mu \mathrm{m}$; Knauer), using methanol as eluent, the sulfur was determined by HPLC from absorption at $265 \mathrm{~nm}$ (detection limit $1 \mu \mathrm{M}$ ).

Sulfate reduction rates. Sulfate reduction rates of whole core incubations were measured in 3 parallel cores of $3 \mathrm{~cm}$ diameter each using the ${ }^{35} \mathrm{SO}_{4}{ }^{2-}$ coreinjection technique (Jørgensen 1978). Sulfate reduction in the anoxic bags was determined at each sampling time-point in subsamples incubated with ${ }^{35} \mathrm{SO}_{4}{ }^{2-}$ radiotracer in $5 \mathrm{ml}$ glass tubes. The incubations were stopped with $\mathrm{Zn}$ acetate. Total reduced inorganic sulfur was analyzed by cold chromium distillation (Kallmeyer et al. 2004).

Oxygen consumption rates. Oxygen consumption rates were measured in 2004 in 3 sediment cores with an inner diameter of $54 \mathrm{~mm}$ closed (without gas phase) with rubber stoppers. The cores were incubated in the dark for 42 to $46 \mathrm{~h}$ at $0^{\circ} \mathrm{C}$ with continuous stirring of the water column by a magnetic stirring bar at the top of the water column (e.g. Canfield et al. 1993a, Glud et al. 1998). Oxygen consumption of the sediment was measured during the whole incubation with a microoptode (Holst et al. 1997). Samples for DIC were taken from the water column of the core before and after oxygen measurement and fixed with $\mathrm{HgCl}_{2}$. The DIC samples were analyzed on a coulometer $\left(\mathrm{CM} 5012, \mathrm{CO}_{2}\right.$ coulometer; CM5130 Acidification module, UIC Coulometrics). The volume of the water column was determined by addition of a $\mathrm{NaBr}$ solution. Concentrations of $\mathrm{NaBr}$ were analyzed by anion chromatography (Dionex DX500; eluent: $9 \mathrm{mM} \mathrm{NaCO}_{3}$ i precolumn: AG9 HC; column: AS9 HC).

Calculation of $\mathrm{Fe}^{2+}$ flux. From the $\mathrm{Fe}^{2+}$ pore water profile, the flux $(J)$ of $\mathrm{Fe}^{2+}$ at $0^{\circ} \mathrm{C}$ was calculated by 
Fick's first law of diffusion: $J=\phi D_{\mathrm{S}} \mathrm{d} C / \mathrm{d} z$, where $\phi$ is porosity, $D_{\mathrm{S}}$ is the diffusion coefficient in the sediment, and $C$ is the solute concentration at a given depth $z . D_{\mathrm{S}}$ was calculated according to Iversen \& Jørgensen (1993): $D_{\mathrm{S}}=D_{0} /[1+3(1-\phi)]$, where $D_{0}$, the diffusion coefficient in sea water, was taken from Schulz \& Zabel (2000, p. 92): $D_{0}\left(\mathrm{Fe}^{2+}\right)=3.1510^{-6} \mathrm{~cm}^{2} \mathrm{~s}^{-1}$ (at $0^{\circ} \mathrm{C}$ ). The net $\mathrm{Fe}^{2+}$ production was calculated from the sum of the $\mathrm{Fe}^{2+}$ fluxes through the upper and lower boundary of each layer.

Enrichment and isolation of pure cultures. Enrichment of bacteria was started with sediments from Stns CC, CD and J collected in 2001. Isolates of Fereducing bacteria were obtained in artificial sea water medium (Widdel \& Bak 1992) of low sulfate concentration $(0.4 \mathrm{mM}$ instead of $28 \mathrm{mM}$ to prevent growth of sulfate reducing bacteria). As electron donors, acetate (20 mM) or lactate $(20 \mathrm{mM})$ were used, and as electron acceptor for the enrichment we used poorly crystalline Fe oxide $(\sim 30 \mathrm{mM})$, which was later replaced by Fe citrate $(\sim 30 \mathrm{mM})$ for isolation in the agar dilution series. Sulfate-reducing bacteria were enriched and isolated similar to Fe-reducing bacteria, but using sulfate (28 mM) instead of Fe(III) as electron acceptor and with lactate $(20 \mathrm{mM})$ or formate $(10 \mathrm{mM})$ as electron donor. Cultures were enriched, isolated, and incubated at temperatures of 4,10 and $17^{\circ} \mathrm{C}$. Growth of bacteria was indicated by the production of $\mathrm{Fe}^{2+}$ for Fe-reducing bacteria or the production of sulfide for sulfate-reducing bacteria.

The nucleotid sequences have been deposited in the GenBank database as follows: Strain 112: AY835388; Strain 102: AY835392; Strain 18: DQ148943; Strain 61: DQ148944; Strain 77: DQ148945; Strain 62: DQ325517; Strain 86: DQ325520; Strain 104: DQ325518; Strain 109: DQ325519.

Some of the isolates have been deposited in culture collections: Strain 102 (Desulfuromusa ferrireducens DSM 16956, JCM 12926), Strain 112 (Desulfuromusa svalbardensis DSM 16958, JCM 12927), Strain 61 (Desulfovibrio ferrireducens, DSM 16995, JCM 12925), Strain 18 (D. frigidus, DSM 17176, JCM 12924).

Growth parameters and physiology. Temperature regulation of respiration of the strains was determined in a temperature-gradient block (Sagemann et al. 1998) at temperatures between -2 and $32^{\circ} \mathrm{C}$. Growth was monitored in duplicate by measuring production of $\mathrm{Fe}^{2+}$ or sulfide. The ability of the strains to use alternative electron acceptors and donors was determined in duplicate tubes after growing cultures had been transferred to new medium for verification. The following electron donors were tested (in combination with Fe citrate or sulfate) (mM): acetate (20), lactate (20), formate (10), propionate (10), butyrate (10), $\mathrm{H}_{2}\left(\mathrm{H}_{2} / \mathrm{CO}_{2}, 80 / 20\right.$, v/v), ethanol (10), propanol (10), butanol (10), fumarate (10) and succinate (10). As electron acceptors the following were tested (in combination with lactate or acetate) (mM): poorly crystalline Fe oxide $(\sim 30)$, Fe citrate $(\sim 30)$, Mn oxide ( 30), elemental sulfur, sulfate (30), thiosulfate (10), sulfite (2), oxygen (air) and fumarate (20).

Fe(III) reduction by Desulfovibrio-related strains. Cells of Strains 18, 61 and 77 were transferred from sulfate-reducing cultures to sulfate-free medium. As substrates, lactate and Fe(III) citrate or poorly crystalline Fe oxide were added. If Fe(III) was reduced, $10 \%$ of the culture was transferred to new medium.

Fe reduction by Strain 61 was investigated in more detail. Cells of Strain 61 were grown by sulfate reduction $(400 \mathrm{ml}$ medium with $28 \mathrm{mM}$ sulfate, $20 \mathrm{mM}$ lactate). In the log phase of growth, the culture was centrifuged for $10 \mathrm{~min}$ and washed twice with $100 \mathrm{ml}$ sulfate-free medium, for which the reducing agent sulfide was replaced by $\mathrm{Fe}(\mathrm{II}) \mathrm{Cl}_{2} \cdot 4 \mathrm{H}_{2} \mathrm{O}$ (2 to $3 \mathrm{mM}$ end concentration). The cells were resuspended in sulfatefree medium in an anoxic glove box and the suspension was filled into serum vials (50 ml each). Lactate $(20 \mathrm{mM})$ and Fe citrate $(\sim 30 \mathrm{mM})$ or Fe oxide $(\sim 30 \mathrm{mM})$ were added to the vials. The incubation temperature was 0 or $20^{\circ} \mathrm{C}$ (triplicates).

Phylogenetic analysis. Universal bacterial primers 8F and 1492R (Buchholz-Cleven et al. 1997) were used to amplify $16 \mathrm{~S}$ rDNA of the isolated strains. The PCR products were amplified with Primers 8F, 341F, 518F, 534R, 1099F and 1492R (Buchholz-Cleven et al. 1997) for sequence analysis (Applied Biosystems Model 3100 Genetic Analyzer DNA sequencer). The sequences were analyzed with the ARB program package (Ludwig et al. 2004). Phylogenetic trees were calculated with the ARB program applying neighbor-joining, maximum-parsimony and maximum-likelihood methods with different sets of filters to a subset of data that included only complete sequences of representative members of Proteobacteria.

\section{RESULTS}

\section{Pore water and solid phase chemistry at Stn J}

The nitrate and nitrite concentrations in the bottom water were 12 and $0.5 \mu \mathrm{M}$, respectively. The dissolved inorganic carbon (DIC) and ammonium concentrations in the pore water increased with increasing depth (Fig. 1A,B). The $\mathrm{Fe}^{2+}$ pore water profile showed a peak at 3 to $4 \mathrm{~cm}(59 \mu \mathrm{M})$ (Fig. 1C) from which we calculated the $\mathrm{Fe}^{2+}$ fluxes from the 1 to $4 \mathrm{~cm}$ depth interval. The fluxes were 4.9 and $2.8 \mathrm{nmol} \mathrm{cm} \mathrm{cm}^{-2} \mathrm{~d}^{-1}$ through the top and bottom layers of the depth interval, respectively, yielding a net $\mathrm{Fe}^{2+}$ production of $2.6 \mathrm{nmol} \mathrm{cm} \mathrm{cm}^{-3} \mathrm{~d}^{-1}$ for the 1 to $4 \mathrm{~cm}$ interval. The sulfate concentration in the pore water was constant in the uppermost $21 \mathrm{~cm}$ of the 


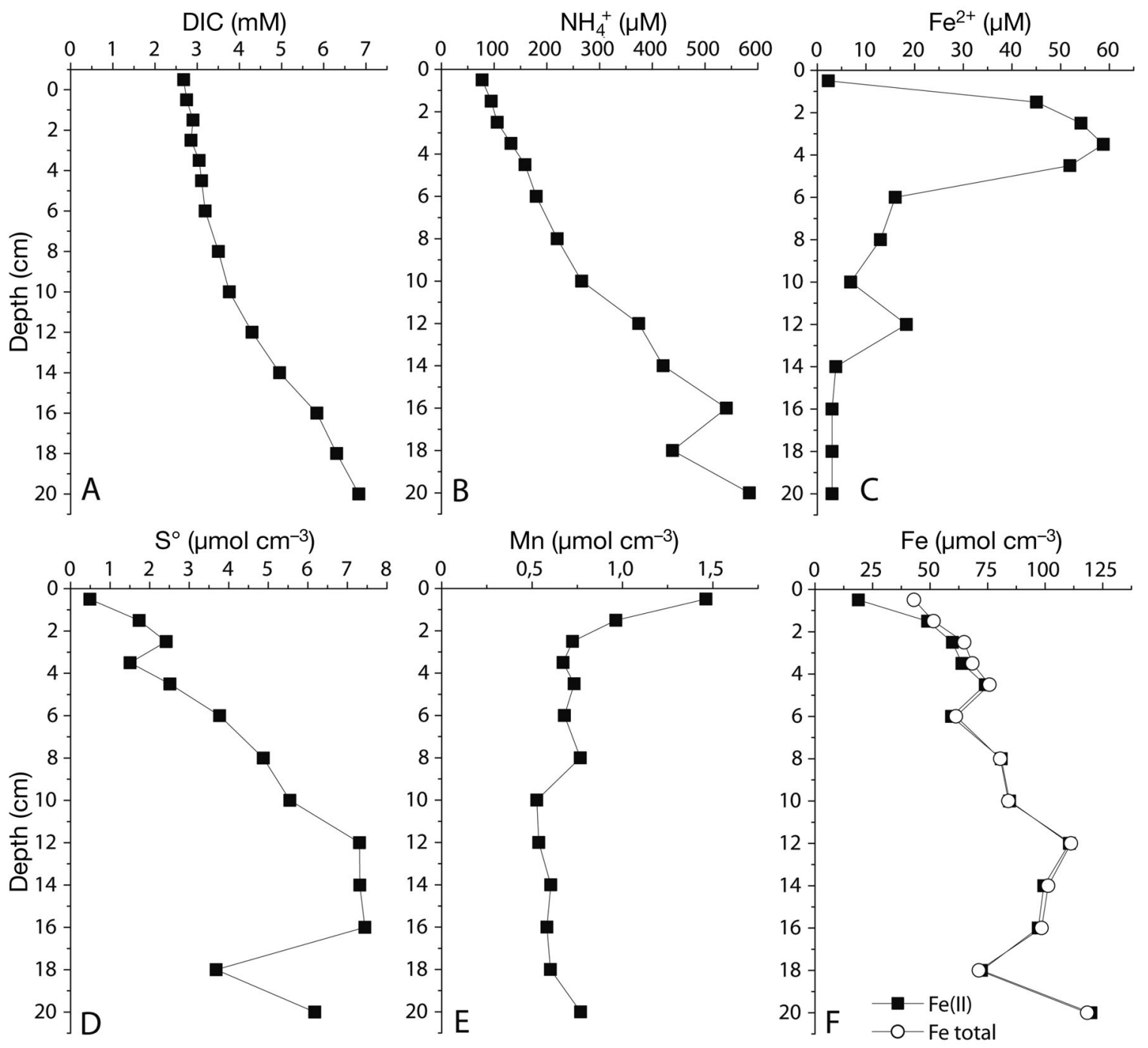

Fig. 1. Pore water dissolved inorganic carbon (DIC), $\mathrm{NH}_{4}{ }^{+}, \mathrm{Fe}^{2+}$ and solid phase $\mathrm{S}^{\circ}, \mathrm{Mn}, \mathrm{Fe}$ constituents of sediment at $\mathrm{Stn} \mathrm{J}$ (see Table 1 for station description)

sediment, and free sulfide did not exceed the detection limit of $1 \mu \mathrm{M}$. Extractable $\mathrm{S}^{\circ}$ increased with increasing depth to $7.4 \mu \mathrm{mol} \mathrm{cm} \mathrm{cm}^{-3}$ at 11 to $17 \mathrm{~cm}$ (Fig. 1D). Mn oxide was enriched near the surface $\left(1.5 \mu \mathrm{mol} \mathrm{\textrm {cm } ^ { - 3 } )}\right.$ and dropped to a stable background level of $\leq 0.8 \mu \mathrm{mol}$ $\mathrm{cm}^{-3}$ below $2 \mathrm{~cm}$ (Fig. 1E). The HCl-extractable Fe(III) concentration decreased from the surface with increasing depth, while the Fe(II) concentration increased (Fig. 1F). The total Fe concentration was on average $78.0 \mu \mathrm{mol} \mathrm{cm} \mathrm{cm}^{-3}$ (Table 1).

\section{Oxygen consumption and sulfate reduction rates in whole core incubations}

The mean total oxygen uptake rate was $4.2 \pm$ $0.4 \mathrm{mmol} \mathrm{m} \mathrm{m}^{-2} \mathrm{~d}^{-1}$ and the DIC release rate $7.1 \pm$ $1.6 \mathrm{mmol} \mathrm{m}^{-2} \mathrm{~d}^{-1}$. Highest sulfate reduction rates were measured between 2 and $4 \mathrm{~cm}$ (Fig. 2), and the mean depth-integrated rate for 0 to $20 \mathrm{~cm}$ was $2.6 \pm 0.6 \mathrm{mmol}$ $\mathrm{m}^{-2} \mathrm{~d}^{-1}$.

\section{Anaerobic carbon mineralization in bag incubations}

Anoxic bags of pooled sediment sections $(1 \mathrm{~cm}$ depth interval each) from the uppermost $5 \mathrm{~cm}$ were incubated at $0^{\circ} \mathrm{C}$. The $\mathrm{Fe}^{2+}$ concentration in the pore water increased in all bags throughout the whole incubation. The rate of $\mathrm{Fe}^{2+}$ accumulation was highest

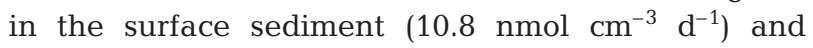
decreased with increasing depth to $0.5 \mathrm{nmol} \mathrm{cm}^{-3} \mathrm{~d}^{-1}$ at 4 to $5 \mathrm{~cm}$ (Fig. $3 \mathrm{~A}$ ). $\mathrm{Mn}^{2+}$ concentrations increased only in bags from the upper $2 \mathrm{~cm}$, with rates of 2.2 and $0.3 \mathrm{nmol} \mathrm{cm} \mathrm{cm}^{-3} \mathrm{~d}^{-1}$ (Fig. 3A), which scaled with the distribution of reactive $\mathrm{Mn}$ (Fig. 1E). In all 5 bags, the 


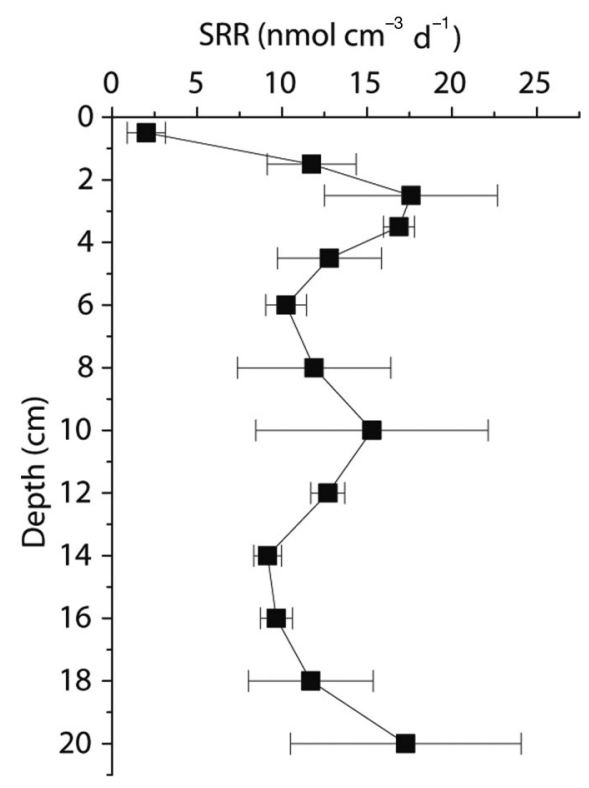

Fig. 2. Mean $( \pm \mathrm{SE} ; \mathrm{n}=3)$ sulfate reduction rates at $\mathrm{Stn} \mathrm{J}$

pore water concentrations of DIC increased linearly throughout the $7 \mathrm{~d}$ incubation, indicating that the reaction rates remained constant and that no precipi-

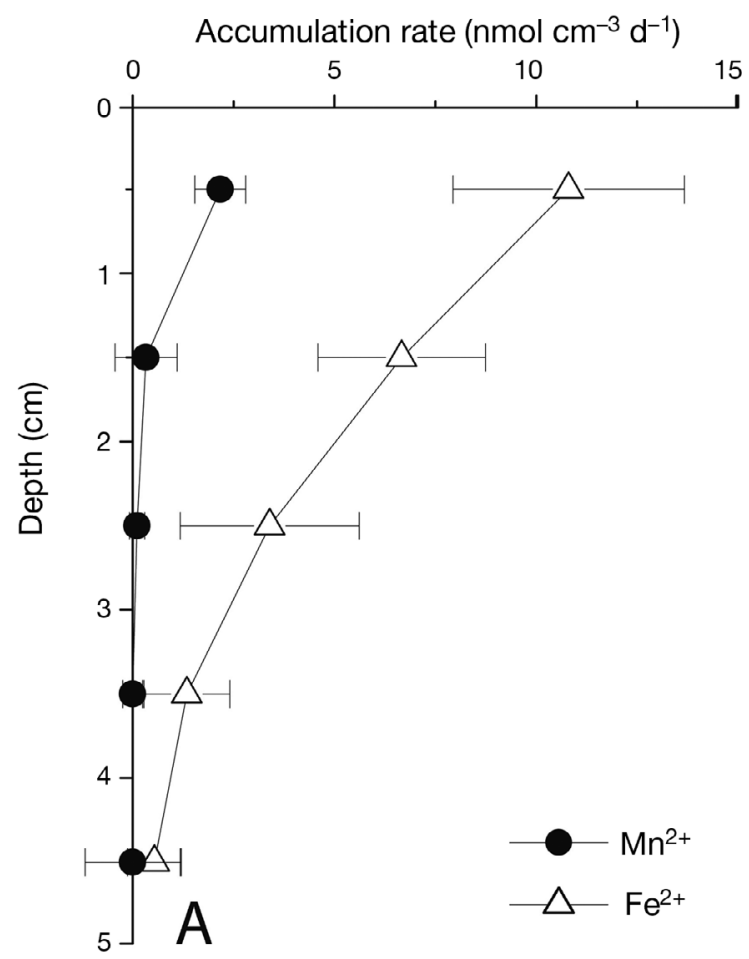

tation of carbonate occurred. This was supported by constant $\mathrm{Ca}^{2+}$ concentrations in the pore water during the incubation (data not shown). The DIC production rate was highest in the surface layer of the sediment and decreased with increasing depth (Fig. 3B), whereas sulfate reduction rates showed no change with depth (Fig. 3B) and were constant over time. DIC accumulation rates matched sulfate reduction rates in the bags from 2 to $5 \mathrm{~cm}$ (Fig. 3B), assuming an overall stoichiometry of 2:1 for DIC production to sulfate reduction as terminal electron acceptor (Thamdrup \& Canfield 1996). In contrast, the 2 rates diverged significantly in the top 0 to $2 \mathrm{~cm}$ of the sediment, indicating that respiration pathways other than sulfate reduction were in operation.

\section{Enrichment and isolation of Fe- and sulfate-reducing bacteria}

For enrichment of bacteria from the 3 stations, we chose as electron donors acetate, lactate and formate, as these are important fermentation products in marine sediments. Using acetate and Fe(III), we isolated 2 strains (Strains 112 and 102) related to species of the

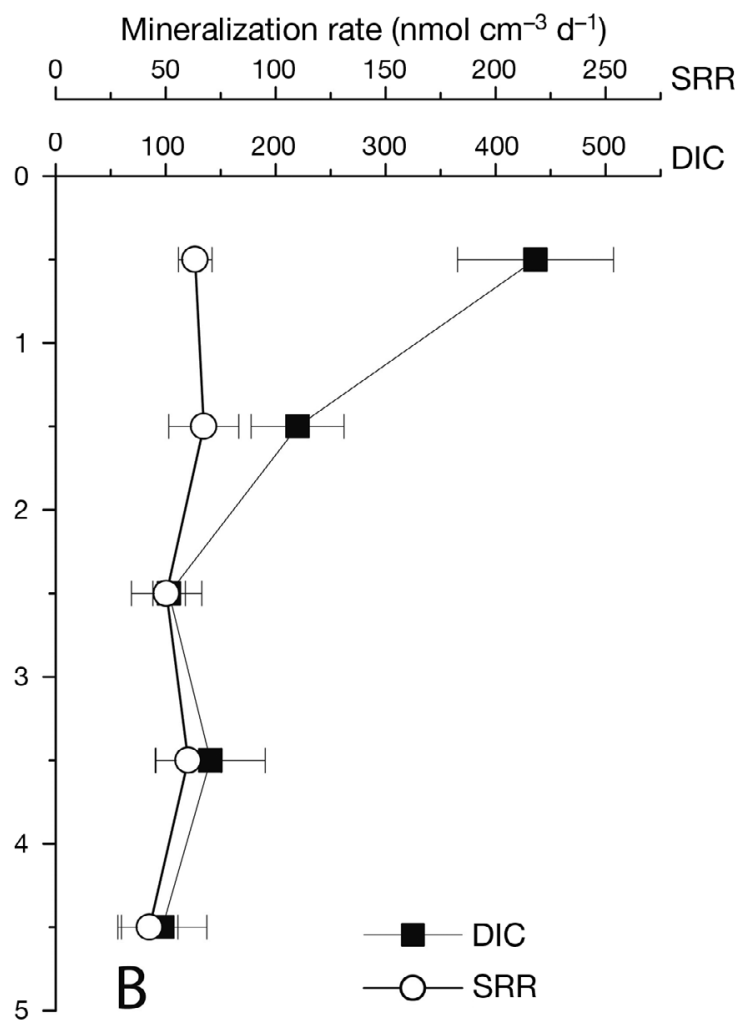

Fig. 3. Accumulation and mineralization rates measured during anoxic bag incubation. (A) Depth distribution of dissolved Fe ${ }^{2+}$ and $\mathrm{Mn}^{2+}$ accumulation rates during incubation; error bars: SE of linear regression. (B) Depth profiles of anaerobic mineralization of organic carbon; error bars: SE of linear regression of DIC production rates and standard deviation of sulfate reduction rates

(SRR). Scales plotted at ratio of 2:1 for DIC production and SRR 


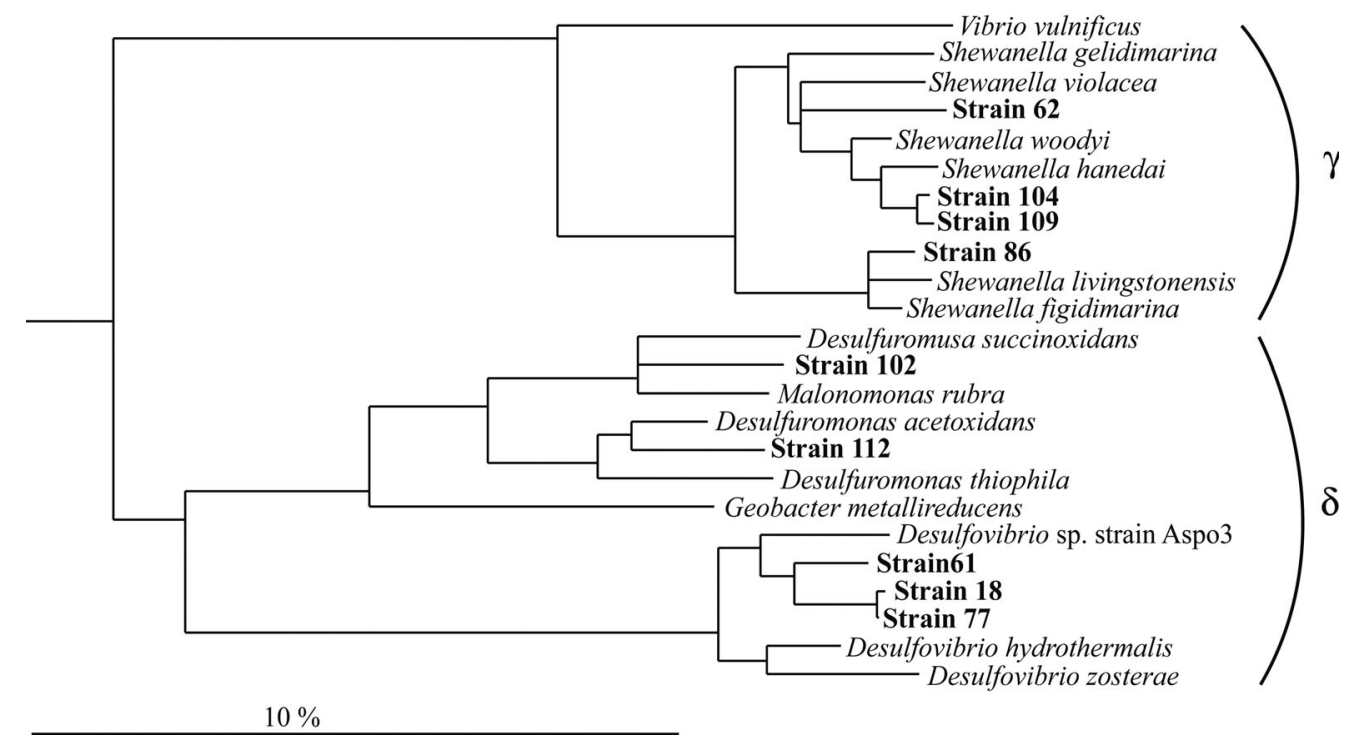

Fig. 4. Phylogenetic tree based on $16 \mathrm{~S}$ rDNA sequences of isolated bacteria and reference sequences of $\gamma$ - and $\delta$-subclasses of Proteobacteria. Scale bar indi-

$\delta$ cates $10 \%$ sequence divergence. Consensus tree evaluated according to results of maximumlikelihood, neighbor-joining and maximum-parsimony analyses. Multifurcation indicates topologies that could not unambiguously be resolved

Geobacteraceae within the $\delta$-Proteobacteria (Fig. 4) (Vandieken et al. 2006b). Within the $\gamma$-Proteobacteria, and closely related to species of the genus Shewanella, Strains 62, 86, 104, and 109 were isolated by lactate oxidation coupled with Fe reduction (Fig. 4).

Table 2. Characterization of isolated strains. Station: station where strain was originally isolated (details in Table 1). +: substrate used for growth $;$-: substrate not used for growth; $(+)$ : substrate used by some strains; $+^{*}$ : substrate reduced but no growth observed. Data for Strains 102 and 112 from Vandieken et al. (2006b), data for Strains 18, 61, 77 from Vandieken et al. (2006a)

\begin{tabular}{|c|c|c|c|c|}
\hline Characteristic & 102 & 112 & $62,86,104,109$ & $18,61,77$ \\
\hline Related genus & $\begin{array}{l}\text { Desulfuro- } \\
\text { musa }\end{array}$ & $\begin{array}{l}\text { Desulfuro- } \\
\text { monas }\end{array}$ & Shewanella & Desulfovibrio \\
\hline Station & $\mathrm{CD}$ & $\mathrm{J}$ & $\mathrm{CC}, \mathrm{CD}, \mathrm{J}$ & $\mathrm{CC}, \mathrm{CD}, \mathrm{J}$ \\
\hline Optimum $\mathrm{T}\left({ }^{\circ} \mathrm{C}\right)$ & $14-17$ & 14 & $\sim 15$ & $20-23$ \\
\hline $\mathrm{T}\left({ }^{\circ} \mathrm{C}\right)$ range for growth & h $-2-23$ & $-2-20$ & $-2-20$ & $-2-30$ \\
\hline \multicolumn{5}{|l|}{ Electron acceptors } \\
\hline Fe oxide / Fe citrate & + & + & + & $+^{*}$ \\
\hline Mn oxide & + & + & + & - \\
\hline Elemental sulfur & + & + & - & $(+)$ \\
\hline Sulfate & - & - & - & + \\
\hline Thiosulfate & - & - & - & $(+)$ \\
\hline Sulfite & - & - & - & + \\
\hline Oxygen & - & - & + & - \\
\hline Fumarate & + & + & $(+)$ & - \\
\hline \multicolumn{5}{|l|}{ Electron donors } \\
\hline Acetate & + & + & $(+)$ & - \\
\hline Lactate & + & - & + & + \\
\hline Formate & + & - & + & + \\
\hline Propionate & - & + & - & - \\
\hline Butyrate & - & - & - & - \\
\hline Hydrogen & + & - & + & + \\
\hline Ethanol & + & + & - & + \\
\hline Propanol & + & + & - & $(+)$ \\
\hline Butanol & + & + & - & - \\
\hline Fumarate & + & - & - & + \\
\hline Succinate & + & - & - & $(+)$ \\
\hline
\end{tabular}

Strain 61, related to species of the genus Desulfovibrio within the $\delta$-Proteobacteria (Fig. 4), was isolated under Fe-reducing conditions with lactate as electron donor (Vandieken et. al 2006a). We isolated 2 strains closely related to Strain 61 (Strains 18 and 77; Fig. 4) by sulfate reduction (28 $\mathrm{mM}$ sulfate) with formate and lactate (Vandieken et al. 2006a).

\section{Characterization of isolated strains}

All isolates were able to grow at $-2^{\circ} \mathrm{C}$ (Table 2). For the strains related to Shewanella, Desulfuromonas, and Desulfuromusa/Malonomonas, highest $\mathrm{Fe}$ reduction rates were measured at $\sim 15^{\circ} \mathrm{C}$ (Table 2 ), and the bacteria are therefore true psychrophiles. The 3 strains related to Desulfovibrio grew best (by sulfate reduction) between 20 and $23^{\circ} \mathrm{C}$, although they were isolated at different temperatures $(4,10$ and $17^{\circ} \mathrm{C}$ ) (Table 2), and can be characterized as psychrotolerants.

The substrate utilization of the isolated strains is shown in Table 2. In addition to Fe(III), the strains reduced electron acceptors such as oxygen, Mn oxide, elemental sulfur and sulfate. Beside acetate and lactate, the strains oxidized other important fermentation products such as formate, hydrogen and propionate.

For all Desulfovibrio-related strains $(18,61$ and 77$)$, the reduction of ferric citrate and poorly crystalline Fe oxide 
was tested at their respective isolation temperature, and 2 to 4 transfers with significant Fe reduction in sulfate-free medium were possible (data not shown). Nevertheless, the cultures reduced the Fe slower with every transfer, and we suggest that this was due to dilution, as microscopic observations showed that no growth occurred. The ability of Strain 61 to reduce Fe was studied in more detail. Cells grown under sulfatereducing conditions were washed with sulfate-free medium and incubated with ferric citrate or poorly crystalline $\mathrm{Fe}$ oxide as sole electron acceptor at 0 or $20^{\circ} \mathrm{C}$. Besides being sulfate free, the medium was reduced with $\mathrm{Fe}$ (II) instead of sulfide to exclude an internal S-cycle with Fe(III) as oxidant for sulfide. The reduction of ferric citrate without sulfate was fast at temperatures of 0 and $20^{\circ} \mathrm{C}$ (Fig. 5). With poorly crystalline Fe oxide reduction of $\mathrm{Fe}(\mathrm{III})$ at $20^{\circ} \mathrm{C}$ was as fast as the reduction of ferric citrate at $0^{\circ} \mathrm{C}$, but $\mathrm{Fe}$ oxide was not reduced at $0^{\circ} \mathrm{C}$. We presume that the low temperature prevented the establishment of certain threshold conditions in the medium (e.g. redox potential) or of microniches necessary for Strain 61 to start reduction of Fe oxide. In all Fe-reducing cultures of Strain 61, these bacteria did not seem to gain energy for growth, as indicated by consistently low bacterial counts (data not shown).

\section{DISCUSSION}

\section{Benthic carbon mineralization}

The areal oxygen uptake rate for Smeerenburgfjorden sediment was $4.2 \pm 0.4 \mathrm{mmol} \mathrm{m}^{-2} \mathrm{~d}^{-1}$, which is similar to rates measured in other fjord sediments at Sval-

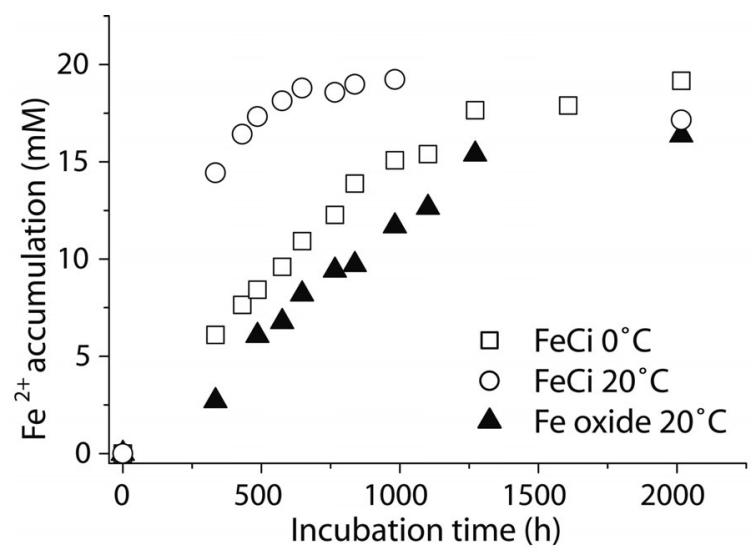

Fig. 5. Fe reduction of ferric citrate (FeCi) and Fe oxide by bacterial Strain 61 in absence of sulfate at 0 and $20^{\circ} \mathrm{C}$ (average of triplicate measurements). Initial $\mathrm{Fe}(\mathrm{II})$ concentration attributable to $\mathrm{FeCl}_{2}$ used as reducing agent of the culture medium has been subtracted bard (3.6 to $8.1 \mathrm{mmol} \mathrm{m}^{-2} \mathrm{~d}^{-1}$ ) (Glud et al. 1998). In another Arctic area along the northeast coast of Greenland, oxygen uptake rates were within the same range at water depths comparable to those at our study site (3.6 to $5 \mathrm{mmol} \mathrm{m}^{-2} \mathrm{~d}^{-1}$ ) (Rysgaard et al. 1998, Glud et al. 2000).

The depth-integrated sulfate-reduction rate of whole core incubations at Stn $\mathrm{J}$ of $2.6 \pm 0.6 \mathrm{mmol} \mathrm{m}^{-2} \mathrm{~d}^{-1}(0$ to $20 \mathrm{~cm}$ ) was within the range measured in other fjord sediments from the west coast of Svalbard (0.9 to $4.1 \mathrm{mmol} \mathrm{m}^{-2} \mathrm{~d}^{-1}$ ) (Sagemann et al. 1998, Knoblauch et al. 1999, Finke 2003). The depth-integrated sulfate reduction rate of the bag incubations $\left(2.8 \mathrm{mmol} \mathrm{m}^{-2}\right.$ $\mathrm{d}^{-1}, 0$ to $5 \mathrm{~cm}$ ) was 5 -fold higher than the rates of whole core incubations for the same sediment interval, indicating a stimulation that is probably due to sediment mixing inside the bags. A similar stimulation was reported previously for fjord sediments of Svalbard (Kostka et al. 1999, Arnosti et al. 2005). The stimulation might be due to a more homogeneous distribution of substrates or the death of benthic fauna which increased the amount of fresh organic material. We believe that the relative stimulation was similar for the different anaerobic pathways of respiration, since experimental addition in substrate to the sediment resulted in similar relative increases in sulfate and $\mathrm{Fe}$ reduction (data not shown).

The anaerobic carbon oxidation rate in sediment bag incubations was similar to rates for permanently cold sediments as well as comparable temperate sediments. The depth-integrated anaerobic DIC production rate was $10.0 \mathrm{mmol} \mathrm{m}^{-2} \mathrm{~d}^{-1}$ at 0 to $5 \mathrm{~cm}$. In previous studies measuring depth intervals of 9 or $10 \mathrm{~cm}$, rates were 11 to $24 \mathrm{mmol} \mathrm{m} \mathrm{m}^{-2} \mathrm{~d}^{-1}$ in fjord sediments of Svalbard (Kostka et al. 1999), 6 and $12 \mathrm{mmol} \mathrm{m}^{-2} \mathrm{~d}^{-1}$ in coastal sediments of Greenland (Rysgaard et al. 1998, Glud et al. 2000), 8 to $40 \mathrm{mmol} \mathrm{m}^{-2} \mathrm{~d}^{-1}$ in sediments of Denmark and Norway (Canfield et al. 1993a, Kostka et al. 1999, Jensen et al. 2003), and 9.2 and $12 \mathrm{mmol} \mathrm{m}^{-2} \mathrm{~d}^{-1}$ in sediments of the Chilean slope (Thamdrup \& Canfield 1996). We conclude that rates of carbon mineralization in Smeerenburgfjorden are similar to those of comparable permanently cold and temperate sediments, and that the benthic microbial community is adapted to the permanently low temperature.

\section{Fe and Mn reduction}

In contrast to oxygen uptake and sulfate reduction rates, a method for direct quantification of Fe reduction rates in sediment cores is currently not available. The most commonly used approach for marine sediments is to perform anoxic sediment incubations, whereby the excess of anaerobic carbon oxidation 
that is not coupled to sulfate reduction is attributed to other available electron acceptors such as $\mathrm{Mn}$ or Fe oxides (Thamdrup 2000).

Sulfate reduction rates matched DIC production rates (assuming a stoichiometry of 2:1 mol of carbon oxidized to sulfate reduced) in the anoxic bag incubation at 3 to $5 \mathrm{~cm}$ sediment depth (Fig. 3B). At 0 to $2 \mathrm{~cm}$, the carbon oxidation rates clearly exceeded the carbon oxidation coupled to sulfate reduction (Fig. 3B). The excess DIC production is attributed to electron acceptors other than sulfate. We excluded oxygen and nitrate reduction because the maximum possible oxygen and nitrate contents would have been reduced within less than $3 \mathrm{~h}$, i.e. before the first sampling timepoint (calculations based on oxygen [311 $\mu \mathrm{M}]$, nitrate [12 $\mu \mathrm{M}]$, and nitrite $[0.5 \mu \mathrm{M}]$ concentrations in the bottom water, an oxygen-penetration depth of $0.6 \mathrm{~cm}$ and an oxygen-consumption rate of $4.2 \mathrm{mmol} \mathrm{m}^{-2} \mathrm{~d}^{-1}$ ). The maximum DIC produced by this oxygen and nitrate reduction in the bags would be $<3 \%$ of the complete DIC concentration increase measured during bag incubations. Thus, the contribution of these processes to the carbon oxidation in the bags was negligible. Because of the low content of reactive Mn oxide in comparison to $\mathrm{Fe}, \mathrm{Mn}$ reduction was probably mainly mediated by abiotic oxidation of $\mathrm{Fe}(\mathrm{II})$ and microbial Mn reduction was only of minor importance (Canfield et al. 1993b). Therefore, we attribute the carbon oxidation in the uppermost $2 \mathrm{~cm}$ that was independent of sulfate reduction to microbial $\mathrm{Fe}(\mathrm{III})$ reduction (Fig. 3B). This is supported by the $\mathrm{Fe}^{2+}$ accumulation rates in the pore water, which decreased with increasing depth (Fig. 3A). Sulfate reduction contributed $5.7 \mathrm{mmol} \mathrm{m}^{-2} \mathrm{~d}^{-1}$ to the $10.0 \mathrm{mmol} \mathrm{m}^{-2} \mathrm{~d}^{-1}$ depthintegrated DIC-production rate in the bags; the remaining $4.3 \mathrm{mmol} \mathrm{m}^{-2} \mathrm{~d}^{-1}$ ( $43 \%$ of the total anaerobic DIC production) were attributed to microbial Fe(III) reduction.

Zones of $\mathrm{Mn}$ and Fe reduction are in general indicated by the accumulation of $\mathrm{Mn}^{2+}$ and $\mathrm{Fe}^{2+}$ in the pore water. Metal liberation rates are, however, often 1 or 2 orders of magnitude lower than the gross metal reduction rates due to adsorption and/or precipitation (Canfield et al. 1993b, Thamdrup \& Canfield 1996, Glud et al. 2000, Thamdrup et al. 2000, Jensen et al. 2003). In our incubation experiment, $\mathrm{Fe}^{2+}$ accumulation rates were similar to rates measured in previous bag incubation experiments with a comparable relative contribution of $\mathrm{Fe}$ reduction to carbon oxidation (Canfield et al. 1993b, Glud et al. 2000). Additionally, the calculated net-production rate of $\mathrm{Fe}^{2+}$ from the pore water profile of $2.6 \mathrm{nmol} \mathrm{cm}{ }^{-3} \mathrm{~d}^{-1}$ at 1 to $4 \mathrm{~cm}$ sediment depth was in good agreement with the net $\mathrm{Fe}^{2+}$ production rates in the bags from the same depth interval, with a mean of $3.4 \mathrm{nmol} \mathrm{cm}^{-3} \mathrm{~d}^{-1}$.
With a pure Fe(III)-reducing culture growing on Fecontaining sands and soils, Roden (2004) showed that 28 to $78 \%$ of the total $\mathrm{Fe}$ (II) production was accounted for by solid phase $\mathrm{Fe}(\mathrm{II})$ accumulation. The $\mathrm{Fe}^{2+}$ accumulation rates in bags from 0 to 1 and 1 to $2 \mathrm{~cm}$ accounted for $<2 \%$ of the calculated Fe reduction rates based on the DIC production rates that were independent of sulfate reduction. A potential sink for Fe(II) in sediments is precipitation with sulfide, (produced during sulfate reduction) to form FeS or pyrite. An indication for this was the black color of the sediment and the fact that $\mathrm{H}_{2} \mathrm{~S}$ was not detected in the pore water throughout the incubation despite high rates of sulfate reduction. Additionally, $\mathrm{Fe}^{2+}$ might adsorb to $\mathrm{Fe}$ or $\mathrm{Mn}$ oxides, be reoxidized by Mn(IV) oxide, or react through other unknown pathways (Van Cappellen \& Wang 1996). On the other hand, we cannot exclude that $\mathrm{Fe}$ (III) oxide was abiotically reduced by sulfide and a quantification was not possible.

In the bag incubations, dissimilatory sulfate and $\mathrm{Fe}$ reduction were measured simultaneously in the uppermost $2 \mathrm{~cm}$, whereas below $2 \mathrm{~cm}$ sulfate reduction was the sole detectable respiration process (Fig. 3B). The overlap of sulfate reduction and metal reduction has also been reported for other habitats, suggesting an incomplete competition for substrates (Canfield et al. 1993b, Kostka et al. 1999, Jensen et al. 2003). For Fereducing bacteria, the availability of reactive Fe(III) oxide is often important in limiting turnover rates (Thamdrup 2000), and competitive inhibition of sulfate reduction by Fe-reducing bacteria is usually not complete. Fe(III) was rapidly depleted in the uppermost $2 \mathrm{~cm}$ of Smeerenburgfjorden sediments (Fig. 1F). Thus, the bacterial Fe-reducing community in these sediments seemed to be mainly limited by Fe(III) rather than by organic carbon.

The relative contribution of microbial Fe reduction to carbon oxidation in situ depends on the faunal activity and sediment accumulation rate, with a high importance of $\mathrm{Fe}$ reduction if the faunal activity is high and the organic carbon deposition is moderate, which results in a deeper mixing zone (Kostka et

Table 3. Rates and contributions of different mineralization pathways to carbon oxidation calculated for 0 to $10 \mathrm{~cm}$ sediment depth interval. Percentages: \% total organic carbon oxidation by each pathway; nd: not determined

\begin{tabular}{|c|c|c|}
\hline Pathway & 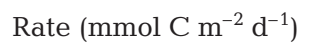 & $\%$ \\
\hline $\mathrm{O}_{2}$ respiration & 3.8 & 53 \\
\hline Denitrification & nd & nd \\
\hline Mn(IV) reduction & $\sim 0$ & $\sim 0$ \\
\hline Fe(III) reduction & 0.9 & 13 \\
\hline $\mathrm{SO}_{4}^{2-}$ reduction & 2.4 & 34 \\
\hline
\end{tabular}


al. 1999). The presence of fauna indicated a high bioturbation and a fast turnover of $\mathrm{Fe}$, which pro bably favor Fe-reducing bacteria in Smeerenburgfjorden sediment.

\section{Pathways of carbon mineralization}

To estimate the relative contribution of the different mineralization pathways for the sediment depth interval of 0 to $10 \mathrm{~cm}$ (Table 3), we used a respective contribution of 43 and $57 \%$ of Fe and sulfate reduction to anaerobic carbon mineralization in the uppermost $5 \mathrm{~cm}$ of the sediment, as determined in the bag incubations. We assumed that below $5 \mathrm{~cm}$ sulfate reduction was the sole terminal respiration pathway. We used whole core sulfate reduction rates $(1.2 \mathrm{mmol}$ $\mathrm{m}^{-2} \mathrm{~d}^{-1}, 0$ to $10 \mathrm{~cm}$ ) to calculate the absolute $\mathrm{Fe}$ reduction rates (Rysgaard et al. 1998), since the processes in the bag incubations were stimulated by the mixing of the sediment. The denitrification rate was not measured and we do not include this pathway in our calculations but assume that it contributed not more than 2 to $3 \%$ to carbon oxidation as described for other fjord sediments at Svalbard (Kostka et al. 1999). Bacterial oxygen consumption was determined from the difference between the DIC release of the whole-core incubations $\left(7.1 \mathrm{mmol} \mathrm{m} \mathrm{m}^{-2} \mathrm{~d}^{-1}\right)$ and the calculated anaerobic DIC production from sulfate and Fe reduction $\left(3.3 \mathrm{mmol} \mathrm{m} \mathrm{m}^{-2} \mathrm{~d}^{-1}, 0\right.$ to $\left.10 \mathrm{~cm}\right)$. These calculations determined aerobic respiration to be the most important mineralization pathway in 0 to $10 \mathrm{~cm}$ sediment depth at Stn J (53\%), and sulfate reduction as the second most important (34\%). The contribution of $\mathrm{Fe}$ reduction to total carbon oxidation was $13 \%$. In situ, the contribution of Fe reduction might vary due to competition with oxygen- and nitrate-respiring bacteria for substrate, depending on the supply of oxygen and nitrate from the water column to the sediment by diffusion and bioturbation. A similar contribution of $\mathrm{Fe}$ reduction to carbon oxidation in the uppermost $10 \mathrm{~cm}$ (10 and $26 \%$ ) was shown for sediments of Van Mijenfjorden and Storfjorden on the southwest and southeast coasts of Svalbard (Kostka et al. 1999). In another fjord (Hornsund), however, no contribution of dissimilatory $\mathrm{Fe}$ reduction to carbon mineralization was detected; this was explained by a high sedimentation rate and a shallow mixing zone (Koska et al. 1999). In permanently cold sediments of Greenland, Fe reduction accounted for 21 to $26 \%$ of total mineralization, and in temperate sites such as the coasts of Denmark and Norway and the continental slope of Chile for 0 to $50 \%$ (Canfield et al. 1993a, Thamdrup \& Canfield 1996, Rysgaard et al. 1998, Glud et al. 2000).

\section{Fe-reducing bacteria}

To investigate the bacteria responsible for Fe reduction in the permanently cold sediments of Svalbard, we isolated Fe-reducing strains from 3 fjord sediments with similar Fe contents (Table 1). The isolates belong to the $\delta$ - and $\gamma$-subclasses of Proteobacteria and were characterized with respect to temperature tolerance and substrate utilization (Table 2). As all isolates grew well at the freezing point of sea water at $-2{ }^{\circ} \mathrm{C}$, the strains are adapted to the low in situ temperatures of their habitat. Isolations of bacteria from different physiological groups from sea ice and sediments of Antarctic and Arctic revealed a high abundance of psychrophilic strains, indicating adaptation to permanently low temperature (Knoblauch et al. 1999, Bowman et al. 2003, Brinkmeyer et al. 2003, Knittel et al. 2005).

Of the strains isolated, 2 (Strains 102 and 112) belong to the genera Desulfuromusa/Malonomonas and Desulfuromonas (Fig. 4). These genera, together with Geobacter and Pelobacter, form an important group of Fe-reducing bacteria: the Geobacteraceae within the $\delta$-Proteobacteria (Holmes et al. 2004b). The presence of members of the Geobacteraceae has been shown for various habitats, including freshwater and marine sediments in temperate and permanently cold habitats by cultivation-independent as well as cultivationdependent methods (e.g. Ravenschlag et al. 1999, Purdy et al. 2003, Lovley et al. 2004 and references therein, Mußmann et al. 2005). In the sediments of Smeerenburgfjorden (Stn J) FISH (fluorescence in situ hybridization) analysis showed the highest abundance of Desulfuromonas-Pelobacter (up to $2.2 \%$ of DAPI cell counts) between 0.5 and $3 \mathrm{~cm}$ depth (Ravenschlag et al. 2000), which was within the Fe reduction zone determined in the present study. For the major group of sulfate reducing bacteria, Desulfosarcina-Desulfococcus, highest cell numbers were found below the Fe reduction zone at $2.25 \mathrm{~cm}$ depth (Ravenschlag et al. 2000). However, recent studies indicate that the FISH probe for the Desulfuromonas-Pelobacter group might be unspecific. Nevertheless, $13 \%$ of clones in a bacterial 16S rDNA clone library of another Svalbard fjord sediment were closely related to Desulfuromonas species (Ravenschlag et al. 1999). Together with the isolation of the psychrophilic Strains 102 and 112, we suggest that the group Geobacteraceae is present in fjord sediments on the west coast of Svalbard. An important characteristic of the isolated Strains 112 and 102, and of other species of this group, is their ability to reduce Fe(III) and elemental sulfur (Table 2). The concentration of $\mathrm{S}^{\circ}$ increased from $0.5 \mu \mathrm{mol} \mathrm{cm} \mathrm{cm}^{-3}$ at the surface to $7.4 \mu \mathrm{mol} \mathrm{cm} \mathrm{cm}^{-3}$ at $16 \mathrm{~cm}$ depth in the sediment of Stn J (Fig. 1D), providing an alternative electron acceptor for strains of the 
Geobacteraceae. Most Geobacteraceae species are able to couple the reduction of Fe(III) and sulfur to the oxidation of acetate (Lovley et al. 2004) (Table 2), which is an important fermentation product in marine sediments including the sediments at Svalbard (e.g. Sørensen et al. 1981, Finke 2003). Thus, these bacteria might play an important role in the sulfur- and Fecycles of marine sediments.

Shewanella is a genus with known psychrophilic Fe-reducing species. All strains isolated with lactate (Strains 62, 86, 104, and 109) in the present study were closely related to the psychrophilic species Shewanella gelidimarina, S. frigidimarina, S. hanedai, S. violacea and $S$. livingstonensis isolated from Antarctic, Arctic or deep-sea sediments (Jensen et al. 1980, Bowman et al. 1997b, Nogi et al. 1998, Bozal et al. 2002) (Fig. 4). Further psychrophilic strains and clone-sequences related to Shewanella were identified in Antarctic and Arctic sea ice and Antarctic shelf sediments (Bowman et al. 1997b, 2003, Junge et al. 2002, Brinkmeyer et al. 2003). Besides permanently cold habitats, strains of this genus have been isolated from a variety of habitats including coastal, open and deep-sea environments and from invertebrates (Ivanova et al. 2004 and references therein), and a wide distribution of this genus is likely. However, their quantitative importance is not understood, since sequences related to Shewanella are generally not found in clone libraries of marine sediments, including the clone library of fjord sediment from Svalbard (Ravenschlag et al. 1999). Facultatively anaerobic strains of Shewanella are well adapted to conditions in surface sediments. Here, oxygen might be an important alternative electron acceptor. In coastal sediments of Svalbard oxygen was found to penetrate 3 to $11 \mathrm{~mm}$ into the sediment (Glud et al. 1998, Kostka et al. 1999), and oxygenated water can be introduced into deeper sediment layers by bioirrigating fauna (Jørgensen et al. 2005). Reactive Mn oxide is typically enriched in surface sediments (Fig. 1E), which can be reduced by the isolated strains related to Shewanella and the Geobacteraceae.

We isolated strains belonging to the genus Desulfovibrio under Fe(III)-reducing as well as sulfatereducing conditions from sediments of all 3 stations, and demonstrated their ability to reduce poorly crystalline and soluble Fe(III) forms in sulfate-free medium. So far, nearly all species of this genus have been isolated by sulfate reduction, but the ability to reduce Fe(III) was demonstrated for some species (Coleman et al. 1993, Lovley et al. 1993, Li et al. 2004). Lovley et al. (1993) suggested, however that, in their experiments, D. desulfuricans obtained energy for growth from the $300 \mu \mathrm{M}$ sulfate present in the medium and not from reduction of Fe(III). Correspondingly, in the present study, it could not be unequivocally determined whether Strain 61 grew during enrichment and isolation by $\mathrm{Fe}(\mathrm{III})$ reduction or by sulfate reduction using the low concentration of sulfate in the medium $(400 \mu \mathrm{M})$. Growth of sulfate-reducing bacteria with Fe as electron acceptor has so far only been reported for Desulfobulbus propionicus and 'Desulfotomaculum reducens' (Tebo \& Obraztsova 1998, Holmes et al. 2004a). In situ reduction of Fe(III) by populations of Desulfovibrio was suggested based on the presence of biomarkers characteristic for Desulfovibrio in a saltmarsh sediment (Coleman et al. 1993). From our results, we conclude that our strains did not grow during $\mathrm{Fe}$ reduction. The $\mathrm{Fe}$ reduction rate of Strain 61 was $12 \mu \mathrm{M} \mathrm{h}^{-1}$ at in situ temperatures (Fig. 5) $\left(0^{\circ} \mathrm{C}, \mathrm{Fe}\right.$ citrate) compared to e.g. $69 \mu \mathrm{M} \mathrm{h}^{-1}$ for the Desulfuromonas-related Strain 112 under the same conditions. Therefore, Desulfovibrio related strains are able to reduce Fe at modestly lower rates compared to other Fe-reducing bacteria. Yet, because of their concurrent growth by sulfate reduction they might also be involved in Fe reduction in their habitat.

In previous investigations of fjord sediments from Svalbard, Desulfovibrio-related strains were not isolated, nor were related sequences found in 16S rDNA libraries (Knoblauch et al. 1999, Ravenschlag et al. 1999). However, from sediments of all 3 stations of Svalbard, we isolated psychrotolerant strains of Desulfovibrio with the ability to reduce the quantitatively important electron acceptors sulfate and Fe.

\section{CONCLUSIONS}

Fe reduction is an important process for the mineralization of organic material in Smeerenburgfjorden (Stn J) sediment. The Strains 112, 109 and 77 isolated from Smeerenburgfjorden represent organisms of all 3 isolated phylogenetic groups (Geobacteraceae, Shewanella and Desulfovibrio). The relatively high Fe(III) content of the sediment provides supportive evidence for microbial Fe reduction in the uppermost $2 \mathrm{~cm}$. The importance of Fe reduction at Stns CC and CD in Tempelfjorden, where the Strains 102, 18, 61, 62, 86 and 104 were isolated, was not determined, but the Fe content at this site was similar to that at Smeerenburgfjorden. However, not only a high Fe content is important for microbial Fe reduction but also high bioturbation and an intermediate sedimentation rate. The isolation of psychrophilic, dissimilatory, Fe-reducing bacteria from all 3 stations shows that this physiological group is present and adapted to low temperatures of permanently cold sediments on the west coast of Svalbard. In marine sediments, Fe(III) additionally might be reduced by sulfate-reducing bacteria. 
Acknowledgements. We thank C. Arnosti, V. Brüchert, O. Larsen, S. Lilienthal, A. Teske and C. Vogt for the enjoyable trips to Svalbard, and especially $M$. Trümper and M. Nickel for assistance with the laboratory work in Ny Ålesund and Longyearbyen. Thanks to S. Henningsen and J. Mortensen for sampling with MS 'Farm'. F. Picardal, C. Knoblauch and M. Mußmann provided essential help with the isolation of bacteria. Thanks to D. Lange for introduction to anaerobic cultivation, M. Alisch for measuring samples with the Dionex, C. Wigand for providing the micro-optodes, and S. Hessler at the University of Bremen for measuring samples with the ICPAES. We thank the Koldewey Station of the Alfred-WegenerInstitut and the University Centre on Svalbard (UNIS) for providing laboratory space. This project was funded by the Max Planck Society.

\section{LITERATURE CITED}

Arnosti C, Jørgensen BB, Sagemann J, Thamdrup B (1998) Temperature dependence of microbial degradation of organic matter in marine sediments: polysaccharide hydrolysis, oxygen consumption, and sulfate reduction. Mar Ecol Prog Ser 165:59-70

Arnosti C, Finke N, Larsen O, Ghobrial S (2005) Anoxic carbon degradation in Arctic sediments: microbial transformations of complex substrates. Geochim Cosmochim Acta 69:2309-2320

Bowman JP, McCammon SA, Brown MV, Nichols DS, McMeekin TA (1997a) Diversity and association of psychrophilic bacteria in Antarctic sea ice. Appl Environ Microbiol 63:3068-3078

Bowman JP, McCammon SA, Nichols DS, Skerratt JH, Rea SM, Nichols PD, McMeekin TA (1997b) Shewanella gelidimarina sp. nov. and Shewanella frigidimarina sp. nov., novel Antarctic species with the ability to produce eicosapentaenoic acid (20:5 $\omega 3)$ and grow anaerobically by dissimilatory Fe(III) reduction. Int J Syst Bacteriol 47:1040-1047

Bowman JP, McCammon SA, Gibson JAE, Robertson L, Nichols PD (2003) Prokaryotic metabolic activity and community structure in Antarctic continental shelf sediments. Appl Environ Microbiol 69:2448-2462

Bozal N, Montes MJ, Tudela E, Jiménez F, Guinea J (2002) Shewanella frigidimarina and Shewanella livingstonensis sp. nov., isolated from Antarctic coastal areas. Int J Syst Evol Bacteriol 52:195-205

Braman RS, Hendrix SA (1989) Nanogram nitrite and nitrate determination in environmental and biological materials by Vanadium(III) reduction with chemi-luminescence detection. Anal Chem 61:2715-2718

Brinkmeyer R, Knittel K, Jürgens J, Weyland H, Amann R, Helmke E (2003) Diversity and structure of bacterial communities in Arctic versus Antarctic pack ice. Appl Environ Microbiol 69:6610-6619

Buchholz-Cleven BEE, Rattunde B, Straub KL (1997) Screening for genetic diversity of isolates of anaerobic Fe(II)oxidizing bacteria using DGGE and whole-cell hybridization. Syst Appl Microbiol 20:301-309

Canfield DE (1989) Reactive iron in marine sediments. Geochim Cosmochim Acta 53:619-632

Canfield DE, Jørgensen BB, Fossing H, Glud R and 6 others (1993a) Pathways of organic carbon oxidation in three continental margin sediments. Mar Geol 113:27-40

Canfield DE, Thamdrup B, Hansen JW (1993b) The anaerobic degradation of organic matter in Danish coastal sediments: iron reduction, manganese reduction, and sulfate reduction. Geochim Cosmochim Acta 57:3867-3883
Cline JD (1969) Spectrophotometric determination of hydrogen sulfide in natural waters. Limnol Oceanogr 14: $454-458$

Coleman ML, Hedrick DB, Lovley DR, White DC, Pye K (1993) Reduction of $\mathrm{Fe}(\mathrm{III})$ in sediments by sulphate-reducing bacteria. Nature 361:436-438

Eilertsen HC, Taasen JP, Weslawski JM (1989) Phytoplankton studies in the fjords of West Spitzbergen: physical environment and production in spring and summer. J Plankton Res 11:1245-1260

Finke N (2003) The role of volatile fatty acids and hydrogen in the degradation of organic matter in marine sediments. $\mathrm{PhD}$ dissertation, University of Bremen, Bremen

Glud RN, Holby O, Hoffmann F, Canfield DE (1998) Benthic mineralization and exchange in Arctic sediments (Svalbard, Norway). Mar Ecol Prog Ser 173:237-251

Glud RN, Risgaard-Petersen N, Thamdrup B, Fossing H, Rysgaard S (2000) Benthic carbon mineralization in a highArctic sound (Young Sound, NE Greenland). Mar Ecol Prog Ser 206:59-71

Grasshoff K, Kremling K, Ehrhardt M (1999) Methods of sea water analysis. Wiley-VCH Verlag, Weinheim

Hall POJ, Aller RC (1992) Rapid, small-volume, flow injection analysis $\Sigma \mathrm{CO}_{2}$ and $\mathrm{NH}_{4}{ }^{+}$in marine and freshwaters. Limnol Oceanogr 37:1113-1119

Holmes DE, Bond DR, Lovley DR (2004a) Electron transfer by Desulfobulbus propionicus to Fe(III) and graphite electrodes. Appl Environ Microbiol 70:1234-1237

Holmes DE, Nevin KP, Lovley DR (2004b) Comparison of $16 \mathrm{~S}$ rRNA, nifD, recA, gyrB, rpoB and fusA genes within the family Geobacteraceae fam. nov. Int J Syst Evol Microbiol 54:1591-1599

Holst G, Glud RN, Kühl M, Klimant I (1997) A microoptode array for fine-scale measurement of oxygen distribution. Sensor Actuator B 38-39:122-129

Hulth S, Hall POJ, Blackburn TH, Landén A (1996) Arctic sediments (Svalbard): pore water and solid phase distribution of C, N, P and Si. Polar Biol 16:447-462

Ivanova EP, Flavier S, Christen R (2004) Phylogenetic relationships among marine Alteromonas-like proteobacteria: emended description of the family Alteromonadaceae and proposal of Pseudoalteromonadaceae fam. nov., Colwelliaceae fam. nov., Shewanellaceae fam. nov., Moritellaceae fam. nov., Ferrimonadaceae fam. nov., Idiomarinaceae fam. nov. and Psychromonadaceae fam. nov. Int J Syst Evol Microbiol 54:1773-1788

Iversen N, Jørgensen BB (1993) Diffusion coefficient of sulfate and methane in marine sediments: influence of porosity. Geochim Cosmochim Acta 57:571-578

Jensen M, Tebo BM, Baumann P, Mandel M, Nealson KH (1980) Characterization of Alteromonas hanedai (sp. nov.), a nonfermentative luminous species of marine origin. Curr Microbiol 3:311-315

Jensen MM, Thamdrup B, Rysgaard S, Holmer M, Fossing H (2003) Rates and regulation of microbial iron reduction in sediments of the Baltic-North Sea transition. Biogeochemistry 65:295-317

Jørgensen BB (1978) A comparison of methods for the quantification of bacterial sulfate reduction in coastal marine sediments I. Measurement with radiotracer techniques. Geomicrobiol J 1:11-27

Jørgensen BB, Glud RN, Holby O (2005) Oxygen distribution and bioirrigation in Arctic fjord sediments (Svalbard, Barents Sea). Mar Ecol Prog Ser 292:85-95

Junge K, Imhoff F, Staley T, Deming JW (2002) Phylogenetic diversity of numerically important Arctic sea-ice bacteria cultured at subzero temperature. Microb Ecol 43:315-328 
Kallmeyer J, Ferdelman TG, Weber A, Fossing H, Jørgensen BB (2004) A cold chromium distillation procedure for radiolabeled sulfide applied to sulfate reduction measurements. Limnol Oceanogr Methods 2:171-180

Kanneworff E, Nicolaisen W (1973) The 'Haps', a frame supported bottom corer. Ophelia 10:119-128

Knittel K, Kuever J, Meyerdierks A, Meinke R, Amann R, Brinkhoff $\mathrm{T}$ (2005) Thiomicrospira arctica sp. nov. and Thiomicrospira psychrophila sp. nov. psychrophilic, obligately chemolithoautotrophic, sulfur-oxidizing bacteria isolated from marine Arctic sediments. Int J Syst Evol Microbiol 55:781-786

Knoblauch C, Jørgensen BB (1999) Effect of temperature on sulphate reduction growth rate and growth yield in five psychrophilic sulphate-reducing bacteria from Arctic sediments. Environ Microbiol 1:457-467

Knoblauch C, Jørgensen BB, Harder J (1999) Community size and metabolic rates of psychrophilic sulfate-reducing bacteria in Arctic marine sediments. Appl Environ Microbiol 65:4230-4233

Kostka JE, Thamdrup B, Glud RN, Canfield DE (1999) Rates and pathways of carbon oxidation in permanently cold Arctic sediments. Mar Ecol Prog Ser 180:7-21

Levitus S, Boyer T (1994) World Ocean atlas, Vol 4: Temperature. Department of Commerce, Washington, DC

Li YL, Vali H, Sears SK, Yang J, Deng B, Zhang CL (2004) Iron reduction and alteration of nontronite NAu-2 by a sulfatereducing bacterium. Geochim Cosmochim Acta 68: 3251-3260

Lovley DR, Roden EE, Phillips EJP, Woodward JC (1993) Enzymatic iron and uranium reduction by sulfatereducing bacteria. Mar Geol 113:41-53

Lovley DR, Holmes DE, Nevin KP (2004) Dissimilatory Fe(III) and Mn(IV) reduction. Adv Microb Physiol 49:219-285

Ludwig W, Strunk O, Westram R, Richter L and 28 others (2004) ARB: a software environment for sequence data. Nucleic Acids Res 32:1363-1371

Mußmann M, Ishii K, Rabus R, Amann R (2005) Diversity and vertical distribution of cultured and uncultured Deltaproteobacteria in an intertidal mud flat of the Wadden Sea. Environ Microbiol 7:405-418

Nogi Y, Kato C, Horikoshi K (1998) Taxonomic studies of deep-sea barophilic Shewanella strains and description of Shewanella violacea sp. nov. Arch Microbiol 170:331-338

Purdy K, Nedwell DB, Embley TM (2003) Analysis of the sulfate-reducing bacterial and methanogenic Archaeal populations in contrasting Antarctic sediments. Appl Environ Microbiol 69:3181-3191

Ravenschlag K, Sahm K, Pernthaler J, Amann R (1999) High bacterial diversity in permanently cold marine sediments. Appl Environ Microbiol 65:3982-3989

Ravenschlag K, Sahm K, Knoblauch C, Jørgensen BB, Amann R (2000) Community structure, cellular rRNA content, and activity of sulfate-reducing bacteria in marine Arctic sediments. Appl Environ Microbiol 66:3592-3602

Editorial responsibility: Otto Kinne (Editor-in-Chief), Oldendorf/Luhe, Germany
Roden EE (2004) Analysis of long-term bacterial vs. chemical Fe(III) oxide reduction kinetics. Geochim Cosmochim Acta 68:3205-3216

Rysgaard S, Thamdrup B, Risgaard-Petersen N, Fossing H, Berg P, Christensen PB, Dalsgaard T (1998) Seasonal carbon and nutrient mineralization in a high-Arctic coastal marine sediment, Young Sound, Northeast Greenland. Mar Ecol Prog Ser 175:261-276

Sagemann J, Jørgensen BB, Greef O (1998) Temperature dependence and rates of sulfate reduction in cold sediments of Svalbard, Arctic Ocean. Geomicrobiol J 15:85-10

Schulz HD, Zabel M (2000) Marine geochemistry. SpringerVerlag, Berlin

Sørensen J, Christensen D, Jørgensen BB (1981) Volatile fatty acids and hydrogen as substrates for sulfate-reducing bacteria in anaerobic marine sediment. Appl Environ Microbiol 42:5-11

Stookey LL (1970) Ferrozine-a new spectrophotometric reagent for iron. Anal Chem 42:779-781

Tebo BM, Obraztsova AY (1998) Sulfate-reducing bacterium grows with $\mathrm{Cr}(\mathrm{VI}), \mathrm{U}(\mathrm{VI}), \mathrm{Mn}(\mathrm{IV})$, and $\mathrm{Fe}(\mathrm{III})$ as electron acceptors. FEMS Microbiol Lett 162:193-198

Thamdrup B (2000) Bacterial manganese and iron reduction in aquatic sediments. Adv Microb Ecol 16:41-84

Thamdrup B, Canfield DE (1996) Pathways of carbon oxidation in continental margin sediments off central Chile. Limnol Oceanogr 41:1629-1650

Thamdrup B, Fleischer S (1998) Temperature dependence of oxygen respiration, nitrogen mineralization, and nitrification in Arctic sediments. Aquat Microb Ecol 15:191-199

Thamdrup B, Rosselló-Mora R, Amann R (2000) Microbial manganese and sulfate reduction in Black Sea shelf sediments. Appl Environ Microbiol 66:2888-2897

Van Cappellen P, Wang Y (1996) Cycling of iron and manganese in surface sediments: A general theory for the coupled transport and reaction of carbon, oxygen, nitrogen, sulfur, iron, and manganese. Am Sci 296:197-243

Vandieken V, Knoblauch C, Jørgensen BB (2006a) Desulfovibrio frigidus sp. nov. and Desulfovibrio ferrireducens sp. nov., two psychrotolerant bacteria isolated from Arctic fjord sediments (Svalbard) with the ability to reduce Fe(III) Int J Syst Evol Microbiol 56:681-685

Vandieken V, Mußmann $M$, Niemann $H$, Jørgensen BB (2006b) Psychrophilic Fe-reducing bacteria isolated from Arctic sediment, Svalbard: Desulfuromonas svalbardensis sp. nov. and Desulfuromusa ferrireducens sp. nov. Int J Syst Evol Microbiol 56:1133-1139

Widdel F, Bak F (1992) Gram-negative mesophilic sulfatereducing bacteria. In: Balows A, Trüper HG, Dworkin $\mathrm{M}$, Harder W, Schleifer KH (eds) The prokaryotes. Springer Verlag, Berlin, p 3352-3378

Zopfi J, Ferdelman TG, Fossing H (2004) Distribution and fate of sulfur intermediates - sulfite, tetrathionate, thiosulfate, and elemental sulfur - in marine sediments. Geol Soc Am Spec Pap 379:97-116

Submitted: August 31, 2005; Accepted: January 16, 2006 Proofs received from author(s): September 4, 2006 